\title{
DOI https://doi.org/10.30525/978-9934-26-115-2-10
}

\section{ІНТЕРАКТИВНІ СИМУЛЯЦІЇ В СИСТЕМІ ЗАСОБІВ ФОРМУВАННЯ ЕКСПЕРИМЕНТАЛЬНИХ УМІНЬ ЗДОБУВАЧІВ ОСВІТИ В УМОВАХ ДИСТАНЦЙНОГО НАВЧАННЯ}

\author{
Слободянюк I. Ю. \\ кандидат педагогічних наук, \\ викладач фізики та інформатики \\ Комунальний заклад вищуӧ освіти \\ «Барський гуманітарно-педагогічний коледж \\ імені Михайла Грушевського» \\ м. Бар, Україна
}

\section{Заболотний В. Ф.}

доктор педагогічних наук, професор, завідувач кафедри фізики і методики навчання фізики, астрономіі

Віннищький державний педагогічний університет імені Михайла Кочююбинського м. Вінничя, Украӥна

Мисліцька Н. А. доктор педагогічних наук, професор, професор кафедри фізики і методики навчання фізики, астрономії Віннищький державний педагогічний університет імені Михайла Кочююбнського м. Вінниця, Украӥна

Фізика є фундаментальною наукою, що вивчає загальні закономірності перебігу природних явищ, закладає основи світорозуміння на різних рівнях пізнання природи i дає загальне обгрунтування природничо-наукової картини світу 
[1]. Її вивчення неможливе без використання експерименту, адже це основний метод пізнання природничих наук. Експериментальна складова навчання фізики реалізується через систему фізичного експерименту, який найефективніше втілює діяльнісний підхід до навчання [2, с. 178].

Події минулого року, пов'язані з пандемією, зумовили кардинальні зміни в організації освітнього процесу, зокрема перехід на дистанційну форму навчання. За досить короткий інтервал часу викладачі вимушені були суттєво змінити форми, засоби, методи, прийоми і способи навчання, в швидкому темпі освоїти новий вид діяльності, до якого долучити і здобувачів освіти.

Пояснення навчального матеріалу без відповідного демонстраційного експерименту не $\epsilon$ цілісним. Стає очевидною необхідність пошуку його практичної реалізації i в умовах дистанційного навчання. Сьогодні великі перспективи вбачаються у використанні дидактичних засобів, які базуються на основі хмаро орієнтованих сервісів, інтерактивних освітніх платформ та технології BYOD.

Велику кількість інтерактивних симуляцій, 3D моделей та освітніх відео 3 фізики розміщено на сайтах mozaweb.com [3] та ck12.org [4], які стануть у нагоді як під час пояснення нового матеріалу (рис. 1), так і при виконанні практичних та лабораторних робіт.

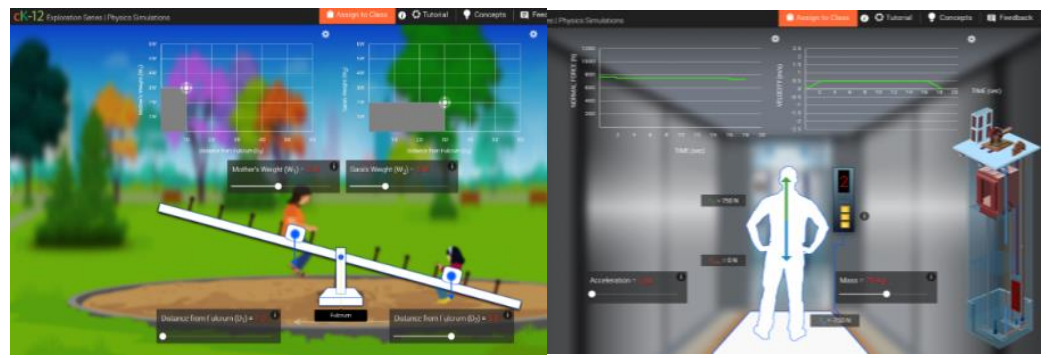

Рис. 1. Приклади віртуальних симуляцій, представлених на web-caйтi ck12.org 
Вивчення предметів природничого циклу передбачає виконання лабораторних робіт, які $\epsilon$ невід'ємною складовою, що забезпечує формування експериментальних умінь та дослідницьких навичок. Однак, в період дистанційного навчання здобувачі освіти не мають доступу до необхідного лабораторного обладнання. У такому випадку доцільно використовувати інтерактивні симуляції та віртуальні online-лабораторні роботи. Сайти «Phet: інтерактивні симуляції» [5] та «Фізика в школі» [6] містять колекцію симуляцій з різних розділів фізики. Розробивши відповідну інструкцію до роботи та додавши посилання на ресурс, викладач надсилає матеріал до виконання (рис. 2, 3).

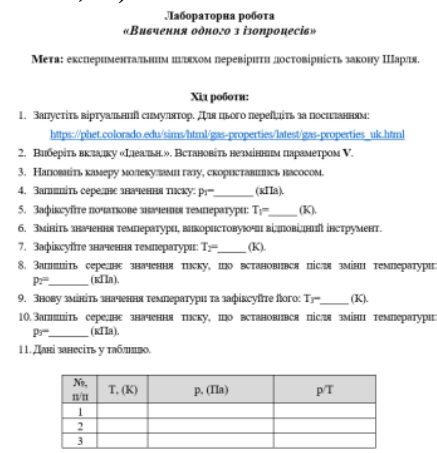

a)

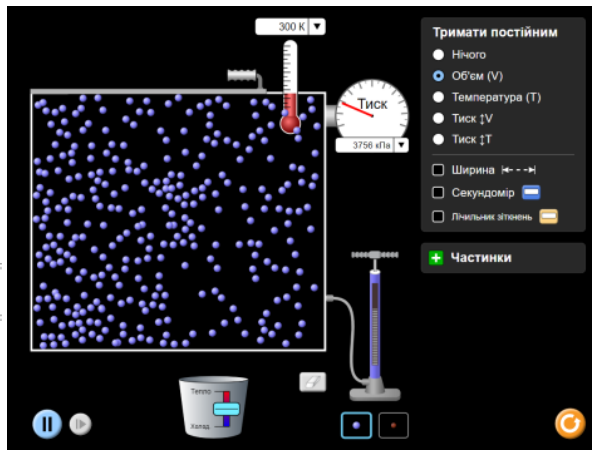

б)

Рис. 2. Фрагмент інструкції до лабораторної роботи «Вивчення одного з ізопроцесів» (а) та віртуального устаткування для її виконання (б) 


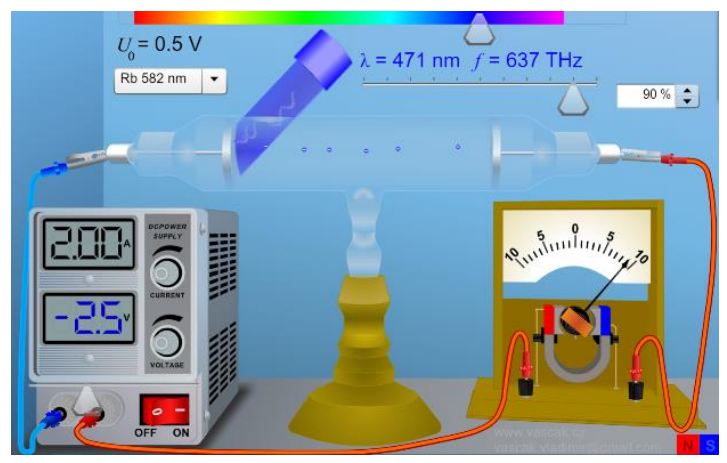

\section{Рис. 3. Віртуальне устаткування для вивчення явища фотоефекту}

Дедалі більшого впровадження набуває технологія BYOD (bring your own device), шо передбачає використання індивідуальних мобільних пристроїв (смартфон, планшет, ноутбук) з метою організації освітньої діяльності. Сучасні смартфони і планшети - це потужні і складні пристрої 3 безліччю схем, плат i датчиків. Їх використання може стати у нагоді здобувачам освіти у проведенні навчальних досліджень. Наприклад, мобільний додаток «Розумні інструменти» налічує понад 40 інструментів та утиліт, серед яких: лінійка, рівнемір, спідометр, компас, детектор магнітного поля, люксметр, метроном, термометр, барометр, акселерометр та інші. Їх використання в освітньому процесі залежить від креативності та творчості викладача.

Сьогодні існує ряд мобільних додатків, які можна використовувати в освітньому процесі для проведення лабораторних робіт. Для цього здобувачам освіти пропонуємо завантажити з колекції додатків (застосунків) (Арр Store, Google Play) відповідний продукт. Наприклад, VoltLab - мобільний додаток, який призначений для дослідження електричних кіл та основних законів електрики. 
Користувач може працювати в двох режимах: навчання та схеми. Режим навчання містить відеоуроки, у ході яких користувачу пояснюють навчальний матеріал, візуалізуючи об'єкти і процеси, які спостерігати в реальному часі неможливо. Режим схем передбачає роботу з готовими схемами електричних кіл та їх ділянками, яких у додатку налічується 18. Зазначимо, що схеми електричних кіл подано як для постійного, так і для змінного струмів. Для кожної схеми користувач на власний розсуд може змінювати режим візуалізації, тобто унаочнення процесів, які відбуваються всередині провідника (рис. 4).
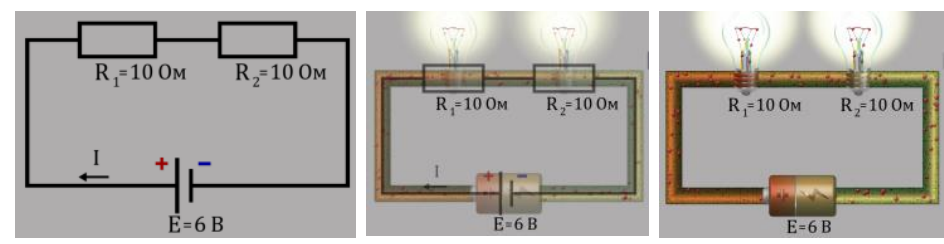

\section{Рис. 4. Різновиди візуалізації в додатку VoltLab}

Таким чином, використання інтерактивних демонстраційних моделей та віртуальних симуляцій дає можливість формувати експериментальні уміння та навички в здобувачів освіти під час дистанційної форми навчання. Проте їх активному використанню повинно передувати формування розуміння сутності, властивостей та основ перебігу явищ, процесів, законів, закономірностей тощо.

\section{Література:}

1. Фізика і астрономія. Навчальні програми для 10-11 класів закладів загальної середньої освіти (авт. кол. під кер. Ляшенка О. I.) [Електронний ресурс] - Режим доступу: https://mon.gov.ua/ua/osvita/zagalna-serednya-osvita/navchalni programi/navchalni-programi-dlya-10-11-klasiv. 
2. Слободянюк I. Ю. Навчальний фізичний експеримент у системі засобів навчання фізики учнів гуманітарних класів // Сучасні інформаційні технології та інноваційні методики навчання в підготовці фахівців: методологія, теорія, досвід, проблеми. 2016. Випуск 44. C. $178-182$.

3. Mozaik Education [Електронний ресурс]. - Режим доступу: https://www.mozaweb.com.

4. CK-12 Foundation [Електронний ресурс]. - Режим доступу: https://www.ck12.org.

5. PhET Interactive Simulations [Електронний ресурс]. Режим доступу: https://phet.colorado.edu.

6. Фізика в школі [Електронний ресурс]. - Режим доступу: https://www.vascak.cz. 